This is an open access article under the CC BY-NC-ND license (https://creativecommons.org/licenses/by-nc-nd/3.0/) Issue III, November 2020

ISSN 2707-9481

ISBN 978-601-323-207-2

https://doi.org/10.31643/2020.005

Putri A. P. a master student of Early Childhood Education Faculty of Graduate School at Yogyakarta State University, Indonesia. E-mail: ayuapriliapangestuputri@gmail.com, ORCID ID: 0000-0002-0927-3182

Kassymova G.

Abai Kazakh National Pedagogical University; Satbayaev University, Kazakhstan Yogyakarta State University, Indonesia E-mail: g.kassymova@satbayev.university ORCID ID: 0000-0001-7004-3864

\section{Suparno S.}

Professor, Dr. (Early Childhood

Education Department) at Yogyakarta

State University, Indonesia.

E-mail: suparno_plb@uny.ac.id

ORCID ID: 0000-0002-9496-1878

\section{Begimbetova G.}

Gymnasium №62, a master student of Abai Kazakh National Pedagogical University, Kazakhstan. E-mail: danka-0810@mail.ru ORCID ID: 0000-0002-0435-1014

\title{
Computer Learning in Early Childhood Education: Survey on Teacher Practice in Preschool
}

\begin{abstract}
This study was conducted to determine the practice of teachers in kindergarten in early childhood computer learning. The participants in the study were kindergartens who carried out early childhood computer learning chosen using purposive sampling method, the sample determined by researchers based on certain characteristics. This research utilized a descriptive approach, where information obtained through a questionnaire is distributed to 25 teachers in Yogyakarta. The questionnaire in this study was adapted from Yurt \& Cevher-Kalburan (2011) concerned with the experience, frequency of use, purpose, and assessment of the activities that children performed with computers in computer learning. The results showed that all teachers obtained computer skills derived from reading documents about computers and exchanging information with their colleagues. This computer learning was carried out on average 1-2 times a week. In addition, the majority of activities held were games for children through computer introduction learning. Early childhood computer learning is more focused on the teacher for aspects of language and children cognitive development.
\end{abstract}

Keywords: computer, early childhood education, survey, teacher and learning.

Cite this article as: Putri, A. P, Suparno S. Kassymova G., Begimbetova G. (2020) Computer Learning in Early Childhood Education: Survey on Teacher Practice in Preschool. Challenges of Science. Issue III, 2020. Pp.: 35-41. https://doi.org/10.31643/2020.005

\section{Introduction}

The abilities and skills to use computer in this era are increasingly important in the digital era. Although computer technology has been invented recently, it a prevalent impact on education system and human development (Kassymova et al, 2019; Atayeva et al., 2019). The importance of information and communication technology in all fields, it is undeniable that computers play an important role in the field of education which means that this becomes a central point in the formation of quality Human Resources (HR) in creating quality personal and independent (Novitasari, 2010). Some information technology can be used as a media of knowledge (educative game) which is the convergence of computers, telecommunications, and learning. The development of information technology itself has actually had a positive impact on the education system in Indonesia in creating a quality generation (Vitianingsih, 2016). This statement is proven 
by several studies which suggest that computers have a positive impact, especially on cognitive, social and emotional aspects and increase children's awareness of the development of current media (Clements \& Sarama, 2003; Trifunović, Čičević, Lazarević, Mitrović1, \& Dragović, 2018). Subsequent research stated that the main factor in children's success in the future is to master information and communication technology, including computers (Ameliola \& Nugraha, 2013). Not only that computers in learning also have an impact on the value of children's affective, for example, coloring activities of the software provided for learning that can stimulate creativity (for example; color composition, new motifs displayed) and make children become enthusiastic, passionate, active, happy and feel satisfaction in learning (Suwarna, 2010), this proves that slowly the form of games with physical instruments in play continuously switches to visual and animated forms (Delima, Arianti, \& Pramudyawardani, 2015). In social-emotional growth, learning using computers involves children in cooperative learning processes because children face difficulties, interact, learning strategies, and group problem solving (Heft \& Swaminathan, 2002).

The benefits that children gain from the teaching of computer introduction are very dependent on the teacher's skills in using and integrating technology (Gimbert \& Cristol, 2004). The contribution of learning carried out can be maximized if the media can be used by educators in the presence of extensive knowledge, based on the curriculum used and the availability of software that supports learning (Sarama \& Clements, 2006). In the introduction of computer learning, teachers are expected to be able to understand the social interactions that occur during the learning process, where the teacher only acts as scaffolding, which means the teacher's task is to help children understand and optimize their development (Greiffenhagen, 2012). It can be said that the teacher has an essential role in learning the introduction of computers to children, the teacher is also an example and role model for children in participating in learning with the teacher's ability to direct and guide learning (Gimbert \& Cristol, 2004). Knowing the practices of teachers in kindergarten in early childhood computer learning is very influential for the success of the teaching that is carried out (Chen \& Chang, 2006).

Computer learning, especially in Indonesia, has been introduced to learning and learning activities in kindergartens such as by using software designed on computer programs as a form of assistance for children in the ability to recognize letters and recognize numbers (Rochanah, 2016). Some researchers have shown that computers can encourage the social development of children (Infante, C., Weitz, J., Reyes, T., Nussbaum, M., Gómez \& Radovic, 2010). Therefore, researchers who have researched computer learning can be used as material for rethinking about the role of technology in early childhood development and result in the development of learning theory and curriculum that meets the needs of contemporary children (Yelland, Lee, O'Rourke, \& Harrison, 2009). While research on teacher practices in kindergarten on early childhood computer learning, especially in regions in Indonesia, is still inadequate. As a result, the lack of data on how the implementation of computer learning conducted by teachers of computer learning in kindergarten. Therefore, this study aims to determine the practice of teachers in early childhood computer learning, especially in the Special Region of Yogyakarta.

\section{Method}

This study was conducted using quantitative approaches, and descriptive methods will enable the description of teacher practices in kindergarten towards early childhood computer learning. A total of 25 teachers from four kindergartens in Yogyakarta were selected as samples in the study using purposive sampling with the consideration that these four kindergartens have carried out and conducted computer learning. Data collection was obtained from filling out questionnaires distributed to kindergartens who were the subjects of the study. Then the information collected in the study is as follows.

Table 1. Demographic Information of the teacher

\begin{tabular}{llcc}
\hline Variable & Sub-Category & f & \% \\
Educational Degree & D3 & 2 & 8 \\
& Bachelor Degree & 23 & 92 \\
Age & $21-25$ Year-old & 4 & 16 \\
& 26-29 Year-old & 6 & 24 \\
& 30-34 Year-old & 6 & 24 \\
& 35-39 Year-old & 2 & 8 \\
& Above 40 Year-old & 7 & 28 \\
\hline
\end{tabular}




\begin{tabular}{llcc}
\hline Teaching Experience & 1 Year & 1 & 4 \\
& 2 Years & 3 & 12 \\
& 3 Years & 1 & 4 \\
Type of Kindegarten & 5 Years & 5 & 20 \\
& Above 5 Years & 15 & 60 \\
Numbers of Preschool Students & Public & 16 & 64 \\
Types of Computer Program & Private & 9 & 36 \\
& 11 -20 Students & 25 & 100 \\
Computer Lab Availability & Intracurricula & 14 & 56 \\
Internet Connection in Classroom & Extracurricula & 11 & 44 \\
Types of Kindergarten Program & Yes & 11 & 44 \\
\hline
\end{tabular}

As can be seen in table 1,92\% of teachers are educational bachelors and only $8 \%$ have graduated from D3. The highest average age percentage of teachers is $28 \%$ over 40 years, $24 \%$ respectively at ages $26-29$ years and 30-35 years with a maximum length of teaching $60 \%$ over 5 years. In addition, $64 \%$ of kindergartens are in the state kindergarten and 36\% are private kindergarten with 11-20 students participating in computer learning. 56\% of computer introductory learning in kindergarten is included in obligatory learning activities that are not carried out in computer labs while $44 \%$ is included in extracurricular activities that are carried out in computer labs. In addition, all kindergartens in this study implemented the halfday program and did not provide internet network services in the implementation of these learning activities. In this study, general information obtained from questionnaires distributed with question items consisted of multiple choices that the teacher had to choose regarding the implementation of computer learning such as the data above. The questions contained in the questionnaire distributed were adapted from the research of Yurt \& Cevher-Kalburan (2011) regarding the thoughts and practices of teachers learning computer introductions held in Turkey. The data obtained is used as statistical data to obtain the desired information, then analyzed using the SPSS 22.0 program and presented in the form of percentage and frequency distribution in each item.

\section{Findings and Discussion}

The results of this study are divided into three categories; 1) Teachers' perspectives on computer learning in early childhood education (Table 2); 2) The practice of computer learning; and 3) Evaluation activities in early childhood computer learning.

Table 2. Teacher Perspectives towards the Computer Learning in Early Childhood

\begin{tabular}{|c|c|c|c|}
\hline Question Itema & Respon & $\mathbf{f}$ & $\%$ \\
\hline Is the learning of computer suitable for preschool students? & Suitable & 25 & 100 \\
\hline \multirow[t]{2}{*}{ Do the students achieve the learning objectives in computer learning? } & Yes & 23 & 92 \\
\hline & Sometimes & 2 & 8 \\
\hline \multirow[t]{2}{*}{ Is the activity performed in computer learning engaging for the students? } & Yes & 21 & 84 \\
\hline & Sometimes & 4 & 16 \\
\hline Do teachers differentiate the activities for male and female preschool students? & No & 25 & 100 \\
\hline
\end{tabular}

As shown in Table 2, all teachers stated that computer learning was suitable for implementation in early childhood education. In addition, it is evident that $92 \%$ of teachers stated that the goals in computer learning could also be achieved by children while there were $8 \%$ of teachers stating sometimes they could achieve these goals. $84 \%$ of teachers stated that the learning activities were engaging for children and $16 \%$ who stated that sometimes children enjoyed the activities. Further, in the implementation of computer learning, none of the teachers distinguish the types of activities carried out between male and female preschool students.

Previous studies demonstrated that teachers had positive perspectives and practices concerning computer learning in kindergarten (Yurta \& Cevher-Kalburan, 2011). Moreover, further studies stated that teachers had a positive practice towards computer learning supported by several factors such as the 
availability of classroom computers and others (Liua, Tokib, \& Pangea, 2014). Children will show a positive attitude when they show interest, and positive reaction in computer learning activities carried out with their friends (Clements \& Sarama, 2003). This statement supports that computer learning is essential to provide an environment that can help children in solving problems in daily life. Thus, the result of this study is in line with previous studies.

All children in the kindergartens learn on the computer once or twice a week and there are no learning activities for computer introductions carried out 3-4 times a week or every day. Activities undertaken in computer learning include (Tabel 3); 1) 36\% said that sometimes and rarely doing musical activities in learning computer while as many as $28 \%$ had never done such activities; 2) $60 \%$ of teachers often provide writing and math preparation activities while $16 \%$ of teachers do this very often and only $24 \%$ sometimes give these activities to children; 3) $60 \%$ of teachers are very frequent and $40 \%$ often provide activities related to educational games for children; 4 ) the majority of teachers, $68 \%$ who often hold language activities; and 5) $77.3 \%$ of teachers who have never held drama and art activities in learning computer in kindergarten.

Table 3. Computer Learning Practices

\begin{tabular}{|c|c|c|c|c|}
\hline \multirow{12}{*}{$\begin{array}{l}\text { Questions Item } \\
\text { How often are computer introductory } \\
\text { learning activities held? }\end{array}$} & Sub-Item & The Answer & f & $\%$ \\
\hline & once or twice a week & Yes & 25 & 100 \\
\hline & One time a week & Yes & 8 & 32 \\
\hline & & No & 12 & 48 \\
\hline & & Sometimes & 5 & 20 \\
\hline & Does not allow children to operate & No & 11 & 44 \\
\hline & computers & Sometimes & 14 & 56 \\
\hline & Twice or three times a month & Yes & 10 & 40 \\
\hline & & No & 11 & 44 \\
\hline & & Sometimes & 4 & 16 \\
\hline & Three and four times a week & No & 25 & 100 \\
\hline & Everyday & No & 25 & 100 \\
\hline \multirow{15}{*}{$\begin{array}{l}\text { What activities are often done in } \\
\text { learning computer recognition? }\end{array}$} & Musical Activities & Sometimes & 9 & 36 \\
\hline & & Rarely & 9 & 36 \\
\hline & & Never & 7 & 28 \\
\hline & Writing and & Always & 4 & 16 \\
\hline & preparation & Often & 15 & 60 \\
\hline & & Sometimes & 6 & 24 \\
\hline & Education Games & Always & 15 & 60 \\
\hline & & Often & 10 & 40 \\
\hline & Language Activities & Always & 4 & 16 \\
\hline & & Often & 17 & 68 \\
\hline & & Sometimes & 4 & 16 \\
\hline & Drama Activities & Rarely & 5 & 22.7 \\
\hline & & Never & 17 & 77.3 \\
\hline & Art Activities & Rarely & 5 & 22.7 \\
\hline & & Never & 17 & 77.3 \\
\hline \multirow{15}{*}{$\begin{array}{l}\text { What aspects of development have you } \\
\text { developed in computer learning } \\
\text { activities? }\end{array}$} & Religious and Moral Values & Sometimes & 8 & 32 \\
\hline & & Rarely & 7 & 28 \\
\hline & & Never & 10 & 40 \\
\hline & Physical-Motor & Always & 5 & 20 \\
\hline & & Often & 17 & 68 \\
\hline & & Sometimes & 3 & 12 \\
\hline & Language & Always & 5 & 20 \\
\hline & & Often & 20 & 80 \\
\hline & Cognitiv & Always & 20 & 80 \\
\hline & & Often & 5 & 20 \\
\hline & social-emotional & Always & 4 & 16 \\
\hline & & Sometimes & 11 & 44 \\
\hline & & Rarely & 10 & 40 \\
\hline & Art & Rarely & 7 & 28 \\
\hline & & Never & 18 & 72 \\
\hline
\end{tabular}


Meanwhile, in stimulating the developmental aspects that children have, it is shown that by conducting learning activities in the introduction of computers $40 \%$ of teachers state they have never included religious and moral aspects, $28 \%$ are rare and $32 \%$ sometimes stimulate these aspects. As many as $68 \%$ of teachers stated aspects of physical-motor development that were objects of stimulation in the learning, $20 \%$ were very frequent and $12 \%$ rarely stimulated these aspects. In the aspect of language development as much as $80 \%$ of teachers stated often and 20\% very often stimulated these aspects of development. Furthermore, $80 \%$ of teachers stated very often and $20 \%$ often stimulated cognitive aspects through learning computer recognition. Furthermore, $16 \%$ of teachers stated often, $44 \%$ sometimes and $40 \%$ stated that networks stimulated aspects of social emotional development in learning computer recognition. And $72 \%$ of teachers said they had never included art stimulation in computer lessons in kindergartens

There is a statement that says children who practice computers 10 minutes a day can improve their academic abilities (Sarama \& Clements, 2006). This shows that children who participate in these activities get academic improvement because the teachers have a positive attitude in the implementation of the learning. Therefore, the activities carried out by the teacher in computer learning for children can help the abilities they have. It's just that in this study aspects of the development of art, social-emotional and religious and moral values are not so important by the teacher in implementing computer learning for children in the kindergarten.

Tabel 4. Teacher Evaluation Practices in Computer Learning

\begin{tabular}{|c|c|c|c|c|}
\hline Question Items & Sub-item & Respon & $\mathbf{f}$ & $\%$ \\
\hline \multirow{14}{*}{$\begin{array}{l}\text { What do you do in evaluating computer learning } \\
\text { activities for children? }\end{array}$} & \multirow{4}{*}{$\begin{array}{l}\text { Question and Answer } \\
\text { Method }\end{array}$} & Always & 4 & 16 \\
\hline & & Often & 11 & 44 \\
\hline & & Sometimes & 4 & 16 \\
\hline & & Rarely & 6 & 24 \\
\hline & \multirow[t]{2}{*}{ Talking with children } & Always & 6 & 24 \\
\hline & & Often & 19 & 76 \\
\hline & \multirow{3}{*}{$\begin{array}{l}\text { Asking children to paint } \\
\text { about what they feel; }\end{array}$} & Sometimes & 1 & 4 \\
\hline & & Rarely & 3 & 12 \\
\hline & & Never & 21 & 84 \\
\hline & \multirow{3}{*}{$\begin{array}{l}\text { Recording of all learning } \\
\text { activities }\end{array}$} & Sometimes & 6 & 24 \\
\hline & & Rarely & 10 & 40 \\
\hline & & Never & 9 & 36 \\
\hline & \multirow{2}{*}{$\begin{array}{l}\text { Record the child's actions on } \\
\text { the observation sheet }\end{array}$} & Always & 13 & 56 \\
\hline & & Often & 12 & 44 \\
\hline \multirow{7}{*}{$\begin{array}{l}\text { What do you do to evaluate yourself in computer } \\
\text { learning? }\end{array}$} & \multirow{2}{*}{$\begin{array}{l}\text { Seeing the response that } \\
\text { children show when learning }\end{array}$} & Always & 9 & 36 \\
\hline & & Often & 16 & 64 \\
\hline & \multirow{3}{*}{$\begin{array}{l}\text { Record in all learning } \\
\text { activities }\end{array}$} & Sometimes & 6 & 24 \\
\hline & & Rarely & 10 & 40 \\
\hline & & Never & 9 & 36 \\
\hline & \multirow[t]{2}{*}{ make a learning report } & Always & 11 & 44 \\
\hline & & Often & 14 & 56 \\
\hline
\end{tabular}

As shown in table 4 , we can see that as many as $16 \%$ of teachers are very frequent, $44 \%$ are frequent, $16 \%$ are sometimes and $24 \%$ are rarely used in conversational methods in evaluating computer learning activities for children. While $24 \%$ of teachers stated very often and $76 \%$ teachers often used the method of conversing in evaluating these activities. The majority of teachers never ask children to paint as evaluation material, as many as $40 \%$ of teachers are rarely and $36 \%$ never record learning activities of evaluation activities, most teachers $56 \%$ very often and $44 \%$ often use child observation sheets as evaluations of their learning.

Evaluation in learning is important in order to correct deficiencies that occur and to optimize aspects of development when children participate in learning (Hariwijaya \& Sukaca, 2009). In the evaluation process, children should get knowledge and motivation from their teachers through strategies and results obtained in order to improve before the children get more recent information (Yurta \& Cevher-Kalburan, 2011) supported by technology that guides teachers positively during children's evaluations. Teachers should make observations for each child to support computer learning that children do. This means that the teacher evaluates by observing the child in accordance with the results of the study that have been obtained in the research results. 


\section{Conclusion}

Digital competence is great of importance nowadays; we need it in every aspect of lifespan. Intersubjective management is a leading aspect of the development of the dynamic abilities of educational enterprises in general (Aprentieva et al, 2019). This study aimed to describe computer learning in kindergarten especially in the practice of early childhood education. In this research, it is known that there are four kindergartens that involve computers as a means of learning and learning both in intactulicular and extracurricular activities. The teacher considers the activities carried out in these activities are in accordance with early childhood, with the availability of fun activities for children. The kindergarten is implementing a half day program and teachers who are trusted in teaching computer learning to the majority of children have taught for more than five years. In computer learning itself, it is done 1-2 times a week where activities such as educational games, writing and math skills, language skills are given more to children compared to drama and art. Computer learning is also more aimed at stimulating aspects of cognitive language development compared to other aspects of development possessed by children. Furthermore, the activities that teachers often do in evaluating children's learning activities are by noting the child's observation sheet. Meanwhile, to evaluate themselves in the activity the majority of teachers from table 4 , we can see that as many as $16 \%$ of teachers are very frequent, $44 \%$ are frequent, $16 \%$ are sometimes and $24 \%$ are rarely using the method of conversing in the evaluation activities computer learning for children. While $24 \%$ of teachers stated very often and $76 \%$ of teachers often used the method of conversing in evaluating these activities. The majority of teachers never see the response that children give when the learning process takes place and make a daily report of the results of computer learning that is done.

Acknowledgement: This research was supported by Yogyakarta State University in Indonesia. Authors would like to gratefully thank the participants in this study.

Cite this article as: Putri, A. P, Suparno S. Kassymova G., Begimbetova G. (2020) Computer Learning in Early Childhood Education: Survey on Teacher Practice in Preschool. Challenges of Science. Issue III, 2020. Pp.: 35-41. https://doi.org/10.31643/2020.005

\section{Refrences}

Ameliola, S., \& Nugraha, H. D. (2013). Perkembangan Media Informasi dan Teknologi Terhadap Anak di Era Globalisasi. International Conferences in Indonesian Studies: "Etnicity and Globalization"

Arpentieva, M. R., Kassymova, G., Kenzhaliyev, O., Retnawati, H., Kosherbayeva, A. (2019). Intersubjective Management in Educational Economy. Challenges of Science. https://doi.org/10.31643/2019.004

Atayeva, M., Putro, N. H. P. S., Kassymova, G., ... Kosbay, S. (2019). Impact of reading on students' writing ability. Challenges of Science. https://doi.org/10.31643/2019.001

Chen, J.-Q., \& Chang, C. (2006). using computers in early childhood classrooms teachers' attitudes,skills and practices. Early Childhood Research. https://doi.org/10.1177/1476718x06063535

Clements, D., \& Sarama, J. (2003). Young children and technology: What does the research say? Young Children, 58(6), 34-40.

Delima, R., Arianti, N. K., \& Pramudyawardani, B. (2015). Identifikasi Kebutuhan Pengguna Untuk Aplikasi Permainan Edukasi Bagi Anak Usia 4 sampai 6 Tahun. Jurnal Teknik Informatika Dan Sistem Informasi, 1(1). https://doi.org/10.21460/inf.2016.121.452

Gimbert, B., \& Cristol, D. (2004). Teaching Curriculum with Technology: Enhancing Children's Technological Competence During Early Childhood. Early Childhood Education Journal, 31(1). https://doi.org/10.1023/b:ecej.0000012315.64687.ee

Greiffenhagen, C. (2012). Making rounds: the routine work of the teacher during collaborative learning with computers. The International Journal of ComputerSupported Collaborative Learning, 7, 11-42. https://doi.org/10.1007/s11412-011-9134-8

Hariwijaya, M., \& Sukaca, B. E. (2009). PAUD: Melejitkan Potensi Anak dengan Pendidikan Sejak Dini. In Potensi Anak (1st ed., p. 16). Yogyakarta: Mahadhika Publishing. https://doi.org/10.31219/osf.io/zk2w6

Heft, T. M., \& Swaminathan, S. (2002). The Effects of Computers on the Social Behavior of Preschool. Jurnal of Reseacrh Early Childhood Education, 6, 162.

Infante, C., Weitz, J., Reyes, T., Nussbaum, M., Gómez, F., \& Radovic, D. (2010). Co-located collaborative learning video game 
with single display groupware. Interactive Learning Environments, 18(2), $177-195$. https://doi.org/10.1080/10494820802489339

Liua, X., Tokib, E. I., \& Pangea, J. (2014). The Use of ICT in Preschool Educationin Greece and China:A Comparative Study. Procedia - Social and Behavioral Sciences, 112, 1167 - 1176. https://doi.org/10.1016/j.sbspro.2014.01.1281

Kassymova, G. (2018). Competence and its implications. Challenges of Science. https://doi.org/10.31643/2018.063

Kassymova, G., Triyono, B., Dossayeva, S., ... Akhmetova, A. (2019). Cognitive competence and electronic learning. Challenges of Science. https://doi.org/10.31643/2019.030

Novitasari, D. R. (2010). Pembangunan Media Pembelajaran Bahasa Inggris Untuk Siswa Kelas 1 Pada Sekolah Dasar Negeri 15 Sragen. Sentra Penelitian Engineering Dan Edukas, Volume 2 N. https://doi.org/10.24114/jtikp.v2i2.3303

Rochanah, L. (2016). Pemanfaatan Media Berbasis Komputer Untuk Meningkatkan Kemampuan Huruf pada Anak Usia Dini (Urgensi Media Berbasis Komputer pada Peningkatan Kemampuan Mengenal Huruf ). Jurnal Program Studi PGRA, Volume 2 N, 1-8. https://doi.org/10.19109/ra.v1i2.2676

Sarama, J., \& Clements, D. H. (2006). Mathematics, Young Students, and Computers: Software, Teaching Strategies and Professional Development. The Mathematics Educato, 9(2), 112-134.

Suwarna. (2010). Pengembangan Multimedia Pembelajaran untuk Pembinaan Kreativitas Melukis di Taman Kanak-kanak. Jurnal Universitas Negeri Yogyakarta. https://doi.org/10.21831/jk.v3i2.6262

Trifunović, A., Čičević, S., Lazarević, D., Mitrović1, S., \& Dragovi, M. (2018). Comparing Tablets (Touchscreen Devices and PCs in Preschool Children Education: Testing Spatial Relationship Using Geometric Syimbols Traffic Signs. IETI Transections on Economics and Safety, 2(1), 35-41. https://doi.org/10.6722/TES.201808_2(1).0004

Vitianingsih, A. V. (2016). Game Edukasi Sebagai Media Pembelajaran Pendidikan Anak Usia Dini. Jurnal INFORM, 1 No. 1.

Wang, F., \& Kinzie, M. B. (2010). Applying Technology to Inquiry- Based Learning in Early Childhood Education. Early Childhood Education Journal. https://doi.org/10.1007/s10643-009-0364-6

Yelland, N., Lee, L., O’Rourke, M., \& Harrison, C. (2009). Rethinking Learning in Early Childhood Education.

Yurta, Ö., \& Cevher-Kalburan, N. (2011). Early childhood teachers' thoughts and practices about the use of computers in early childhood education. Procedia Computer Science, 3, 1562-1570. https://doi.org/10.1016/j.procs.2011.01.050 